\title{
PENGARUH MODEL PROBLEM BASED LEARNING TERHADAP \\ KETERAMPILAN BERPIKIR KREATIF PESERTA DIDIK \\ PADA MATERI PENCEMARAN LINGKUNGAN (Studi Eksperimen di Kelas X SMA Negeri 1 Cihaurbeuti Tahun Ajaran 2015/2016)
}

\section{Endang Surahman ${ }^{1}$, Anne Novia Fitri ${ }^{1}$ e.surahman@unsil.ac.id}

${ }^{1)}$ Program Studi Pendidikan Biologi Fakultas Keguruan dan Ilmu Pendidikan Universitas Siliwangi

\begin{abstract}
The aimed of this research was to know the influence of problem based learning model to creative thinking skills on environmental pollution material in $\mathrm{X}$ grade of SMA Negeri 1 Cihaurbeuti at 2015/2016 academic year.

This research was conducted from November 2015 until March 2016 in X grade of SMA Negeri 1 Cihaurbeuti. The method used in this research was true experiment. The population of this research was all class of $\mathrm{X}$ grade at SMA Negeri 1 Cihaurbeuti as much as 4 classes which consist of 144 student. The sample used in the research which taken by cluster random sampling technique as much as two class, X MIPA 1 as the experimental class and X MIPA 2 as the control class. To measure the creative thingking skills, used an instrument that is a test of the creative thingking skills which consists of 11 questions in the form of essay. Analysis using t test with significance level $\alpha=0,05$.

The result of the research shows there was influence of problem based learning model to creative thinking skills on environmental pollution material (an experimental study in X grade of SMA Negeri 1 Cihaurbeuti academic year 2015/2016).
\end{abstract}

Keywords: problem based learning model, creative thinking skills and environmental pollution

\begin{abstract}
ABSTRAK
Abstrak: Penelitian ini bertujuan untuk mengetahui pengaruh model problem based learning terhadap keterampilan berpikir kreatif peserta didik pada materi Pencemaran Lingkungan di kelas X SMA Negeri 1 Cihaurbeuti tahun ajaran 2015/2016.

Penelitian ini dilaksanakan pada bulan November 2015 sampai dengan bulan Maret 2016 di kelas X SMA Negeri 1 Cihaurbeuti. Metode penelitian yang digunakan adalah true experiment. Populasi dalam penelitian ini adalah seluruh kelas X SMA Negeri 1 Cihaurbeuti tahun ajaran 2015/2016 sebanyak 4 kelas dengan jumlah siswa sebanyak 144 orang. Sampel yang digunakan dalam penelitian ini diambil dengan menggunakan teknik cluster random sampling sebanyak 2 kelas yaitu X MIPA 1 sebagai kelas eksperimen dan X MIPA 2 sebagai kelas kontrol. Untuk
\end{abstract}


Bioedusiana

Volume 01, nomor 01, September 2016

ISSN 2477-5193

mengukur keterampilan berpikir kreatif peserta didik, digunakan instrumen berupa tes keterampilan berpikir kreatif berjumlah 11 butir soal yang berbentuk uraian. Teknik analisis data menggunakan uji t dengan taraf nyata $\alpha=0,05$.

Hasil penelitian menunjukan bahwa ada pengaruh model problem based learning terhadap keterampilan berpikir kreatif peserta didik pada materi Pencemaran Lingkungan di kelas X SMA Negeri 1 Cihaurbeuti tahun ajaran 2015/2016.

Kata Kunci: model problem based learning, keterampilan berpikir kreatif dan pencemaran lingkungan

\section{PENDAHULUAN}

Pendidikan sebagai salah satu sistem yang menjawab tuntutan ini terus mengalami perubahan seiring dengan perkembangan zaman, perubahan tersebut terkait dengan proses pembelajaran. Proses pembelajaran yang mampu mengembangkan potensi dan keterampilan berpikir peserta didik sangat diperlukan dalam era yang terus berkembang pada saat ini. Salah satu keterampilan berpikir tingkat tinggi yang dapat dikembangkan di sekolah adalah keterampilan berpikir kreatif. Berpikir merupakan kegiatan yang melibatkan proses mental untuk dapat mempertimbangkan situasi, merumuskan pengertian, mensintesis, memecahkan suatu masalah hingga akhirnya dapat menarik kesimpulan agar didapatkan solusinya. Sebagaimana yang diutarakan Peter (Sanjaya, Wina, 2011:230) "Bepikir (thinking) adalah proses mental seseorang yang lebih dari sekadar mengingat (remembering) dan memahami (comprehending). Mengingat dan memahami lebih bersifat pasif daripada berpikir (thinking)". Senada dengan pendapat tersebut dikemukakan oleh Arends, Richard I (2008:43) yang menyatakan "Berpikir adalah kemampuan untuk menganalisis, mengkritik, dan mencapai kesimpulan berdasarkan infrensi atau judgment yang baik". Secara lebih luas, Tawil, Muh dan Liliasari (2013:4) menjelaskan "secara umum berpikir merupakan suatu proses kognitif, suatu aktivitas mental untuk memperoleh pengetahuan. Proses berpikir dihubungkan dengan pola perilaku yang lain dan memerlukan keterlibatan aktif pemikir melalui hubungan kompleks yang dikembangkan melalui kegiatan berpikir". Proses yang terjadi ketika berpikir akan terdapat unsur logis dan 
Bioedusiana

Volume 01, nomor 01, September 2016 ISSN 2477-5193

analitis di dalamnya, sebagaimana yang dijelaskan Novak, (Tawil, Muh dan Liliasari, 2013:4) bahwa "berdasar-kan prosesnya berpikir dapat dikelompokkan dalam berpikir dasar dan berpikir kompleks. Proses berpikir dasar merupakan gambaran dari proses berpikir rasional yang mengandung sejumlah langkah dari yang sederhana menuju yang kompleks. Aktivitas berpikir rasional meliputi menghafal, membayangkan, mengelompokkan, mengorganisasikan, membandingkan, mengevaluasi, menganalisis, mensintesis, mendeduksi dan menyimpulkan". Menyambung dari penjelasan Novak, menurut Costa (Tawil, Muh dan Liliasari, 2013:4) bahwa "Berpikir kompleks disebut proses berpikir tingkat tinggi yang terdiri dari berpikir kritis, berpikir kreatif, pemecahan masalah, dan pengambilan keputusan".

Keterampilan berpikir yang baik belum tentu dimiliki oleh orang yang cerdas, karena keterampilan berpikir yang baik akan didapatkan dari sebuah pengalaman maupun kebiasaan. De Bono, (Tawil, Muh dan Liliasari, 2013:24) menyatakan bahwa "Keterampilan berpikir meru- pakan perpaduan antara keterampilan mental dan kecerdasan dengan pengalaman".

Keterampilan berpikir kreatif merupakan suatu kegiatan untuk menghasilkan gagasan baru dalam pemecahan masalah, menemukan ide baru yang sesuai dengan tujuan, dengan cara membangun ide-ide kreatif, mensintesis ide-ide tersebut hingga mampu menciptakan desain maupun produk yang bersifat orisinil. Berpikir kreatif diartikan sebagai suatu kegiatan mental yang digunakan seseorang untuk membangun gagasan-gagasan baru.

Menurut Krulik dan Rudnik (Saefudin, Abdul Aziz, 2012:40) "Berpikir kreatif merupakan salah satu tingkat tertinggi seseorang dalam berpikir, yaitu dimulai ingatan (recall), berpikir dasar (basic thinking), berpikir kritis (critical thinking) dan berpikir kreatif (creative thinking). Munandar, Utami (2012:167) mengutarakan "Berpikir divergen (juga disebut berpikir kreatif) ialah memberikan macammacam kemungkinan jawaban berdasarkan informasi yang diberikan dengan penekanan pada keragaman 
Bioedusiana

Volume 01, nomor 01, September 2016 ISSN 2477-5193

jumlah dan kesatuan”. Selanjutnya Munandar, S.C. Utami (2002:33) mendefinisikan berpikir kreatif sebagai "kemampuan umum untuk mencipta sesuatu yang baru, sebagai kemampuan untuk memberi gagasangagasan baru yang dapat diterapkan dalam pemecahan masalah, atau sebagai kemampuan untuk melihat hubungan-hubungan baru antara unsur-unsur yang sudah ada sebelumnya".

Menurut De Bono, Edward (Tawil, Muh dan Liliasari, 2013:59) "Kita harus berpikir kreatif untuk memperbaiki kehidupan, melakukan inovasi desain, menciptakan perubahan dan memperbaiki sistem". Selanjutnya Edward, Liliasari (Tawil Muh dan Liliasari, 2013:59) memaparkan bahwa "Kemampuan berpikir kreatif sangat menentukan dalam membangun kepribadian dan pola tindakan dalam kehidupan setiap insan Indonesia, karena itu pembelajaran sains perlu diberdayakan untuk mencapai maksud tersebut". Liliasari (Tawil, Muh dan Liliasari, 2013:60) menjelaskan bahwa "keterampilan berpikir kreatif adalah keterampilan mengembangkan atau menemukan ide atau gagasan asli, estetis dan konstruktif, yang berhubungan dengan pandangan dan konsep serta menekankan pada aspek berpikir intuitif dan rasional khususnya dalam menggunakan informasi dan bahan untuk memunculkan atau menjelaskannya dengan perspektif asli pemikir".

Keterampilan berpikir kreatif yang dimaksudkan dalam penelitian ini merupakan aktivitas kognitif yang diukur dari empat aspek meliputi aspek berpikir lancar (fluency), aspek berpikir luwes (flexibility), aspek berpikir orisinil (originality), dan aspek berpikir terperinci (elaboration) dengan menggunakan tes tertulis berbentuk uraian.

Guilford (Munandar, S.C. Utami, 2002:91) mengemukakan mengenai aspek penilaian dalam kreativitas bahwa "Berpikir divergen sebagai operasi mental yang menuntut penggunaan kemampuan berpikir lancar, lentur, orisinil dan terperinci (elaborasi)". Berikut ini aspek dan indikator keterampilan berpikir kreatif dapat dilihat pada tabel 2.2. 
Bioedusiana

Volume 01, nomor 01, September 2016

ISSN 2477-5193

Tabel 2.2 Aspek dan Indikator Keterampilan Berpikir Kreatif

\begin{tabular}{|c|c|c|}
\hline No & $\begin{array}{l}\text { Aspek Keterampilan Berpikir } \\
\text { Kreatif }\end{array}$ & $\begin{array}{c}\text { Indikator Keterampilan Berpikir } \\
\text { Kreatif }\end{array}$ \\
\hline \multirow[t]{3}{*}{1} & \multirow[t]{3}{*}{$\begin{array}{l}\text { Keterampilan Berpikir Lancar } \\
\text { (Fluency) }\end{array}$} & $\begin{array}{l}\text { a. Mencetuskan banyak gagasan, } \\
\text { jawaban, penyelesaian masalah atau } \\
\text { pertanyaan. }\end{array}$ \\
\hline & & $\begin{array}{l}\text { b. Memberikan banyak cara atau saran } \\
\text { untuk melakukan berbagai hal. }\end{array}$ \\
\hline & & $\begin{array}{l}\text { c. Selalu memikirkan lebih dari satu } \\
\text { jawaban. }\end{array}$ \\
\hline \multirow[t]{3}{*}{2} & \multirow[t]{3}{*}{$\begin{array}{l}\text { Keterampilan Berpikir Luwes } \\
\text { (Flexibility) }\end{array}$} & $\begin{array}{l}\text { a. Menghasilkan gagasan, jawaban atau } \\
\text { pertanyaan yang bervariasi. }\end{array}$ \\
\hline & & $\begin{array}{l}\text { b. Memberikan berbagai macam } \\
\text { penafsiran terhadap suatu gambar, } \\
\text { cerita atau masalah. }\end{array}$ \\
\hline & & $\begin{array}{l}\text { c. Menerapkan suatu konsep atau suatu } \\
\text { asas dengan cara yang berbeda-beda. }\end{array}$ \\
\hline 3 & $\begin{array}{l}\text { Keterampilan Berpikir Orisinil } \\
\text { (Originality) }\end{array}$ & $\begin{array}{l}\text { Membuat kombinasi-kombinasi yang } \\
\text { tidak lazim dari bagian-bagian atau } \\
\text { unsur-unsur. }\end{array}$ \\
\hline \multirow[t]{2}{*}{4} & \multirow{2}{*}{$\begin{array}{l}\text { Keterampilan Berpikir Terperinci a } \\
\text { (Elaboration) }\end{array}$} & $\begin{array}{l}\text { a. Mampu memperkaya dan } \\
\text { mengembangkan gagasan dan produk. }\end{array}$ \\
\hline & & $\begin{array}{l}\text { b. Menambahkan atau merinci detail- } \\
\text { detail dari suatu objek, gagasan atau } \\
\text { situasi menjadi menarik. }\end{array}$ \\
\hline
\end{tabular}

Sumber : Munandar, Utami (Rachman, Niken Noviasti, 2013:33)

Suatu pernyataan fundamental atau kebenaran umum yang dijadikan oleh seseorang maupun kelompok sebagai sebuah pedoman dalam berpikir sebagaimana penjelasan Perkins (Tawil, Muh dan Liliasari, 2013:63) bahwa "terdapat lima prinsip umum berpikir kreatif, yaitu 1) estetika berpikir kreatif melibatkan standar praktis. Orang kreatif berusaha ingin tahu sesuatu yang mendasar, luas dan kuat; 2) berpikir kreatif tergantung kepada tujuan yang akan dicapai. Orang kreatif mengeksplorasi tujuan dan menggunakan pendekatan-pendekatan dalam mengenali sifat masalah dan menemukan suatu solusi standar, dan bersedia untuk mengubah pendekatan di kemudian hari, dan bahkan mendefinisikan ulang masalah apabila diperlukan; 3) berpikir kreatif 
Bioedusiana

Volume 01, nomor 01, September 2016

ISSN 2477-5193

lebih cenderung tidak terpusat pada suatu kompetensi. Orang kreatif mempertahankan standar yang tinggi, menerima kebingungan, ketidakpastian dan resiko kegagalan yang lebih tinggi sebagai bagian dari proses dan belajar untuk melihat kegagalan dan bahkan menarik dan menantang; 4) berpikir kreatif lebih banyak bersifat subjektif. Orang kreatif mempertimbangkan berbagai sudut pandang berbeda, melakukan evalusi dan menemukan ide-ide yang praktis; dan 5) berpikir kreatif tergantung pada motivasi instrinsik daripada ekstrinsik. Orang kreatif dapat memilih apa yang harus dilakukan dan bagaimana melakukan. Mereka memahami tugas sebagaimana kompetensi yang mereka miliki, melihat apa yang mereka lakukan sebagai sesuatu yang berharga dalam dirinya sendiri dan menikmati kegiatan yang dilakukan.

Kreativitas merupakan hasil dari proses berpikir kreatif yang dilakukan oleh seseorang. Hasil dari kreativitas adalah ide, gagasan atau konsep. Orang yang kreatif adalah orang yang mempunyai banyak ide. Amabile, dkk (Munandar, S.C. Utami, 2002:29) berpendapat bahwa
"Kreativitas tidak hanya bergantung pada keterampilan dalam bidang dan dalam berpikir kreatif, tetapi juga pada motivasi intrinsik (pendorong internal) untuk bersibuk diri dalam bekerja, dan pada lingkungan sosial yang kondusif (pendorong eksternal)".

Salah satu model pembelajaran yang banyak digunakan untuk menunjang proses pembelajaran student centered adalah model problem based learning. Menurut Hamdayama, Jumanta (2014:209) model problem based learning diartikan sebagai "Rangkaian aktivitas pembelajaran yang menekankan pada proses penyelesaian masalah secara ilmiah".

Secara lebih luas, Torp dan Sage (Abidin, Yunus, 2014:210) memandang model problem based learning "Difokuskan untuk menjembatani siswa agar beroleh pengalaman belajar dalam mengorganisasikan, meneliti, dan memecahkan masalahmasalah kehidupan yang kompleks". Masalah tersebut dipertemukan pertama dalam proses pembelajaran. Selanjutnya, Abidin, Yunus (2014: 158) menyatakan "model pembelajar- 
Bioedusiana

Volume 01, nomor 01, September 2016

ISSN 2477-5193

an yang berbasiskan masalah sebagai hal yang muncul pertama kali pada saat proses pembelajaran. Masalah tersebut disajikan sealamiah mungkin dan selanjutnya siswa bekerja dengan masalah yang menuntut siswa mengaplikasikan pengetahuan dan kemampuan sesuai dengan tingkat kemampuan psikologis dan kemampuan belajarnya.

Adapun menurut Arends

(Hosnan, M, 2014:295) model problem based learning adalah model pembelajaran dengan pendekatan pembelajaran siswa pada masalah autentik sehingga siswa dapat menyusun pengetahuannya sendiri, menumbuhkembangkan keterampilan yang lebih tinggi dan inquiry, memandirikan siswa dan meningkatkan kepercayaan diri sendiri.

Model problem based learning memiliki beberapa karakteristik sebagaimana yang dikemukakan Tan, Oon-Seng (2003:30) sebagai berikut: 1) masalah digunakan sebagai awal pembelajaran; 2) masalah yang digunakan merupakan masalah dunia nyata yang disajikan secara mengambang (ill-structured). Jika itu merupakan simulasi masalah, hal ini dimaksudkan untuk masalah yang bersifat otentik; 3) masalah mendorong lahirnya kemampuan peserta didik berpendapat secara perspektif majemuk (multiple perspektif). Solusinya menuntut siswa menggunakan dan mendapatkan konsep dari lintas ilmu ke bidang lainnya; 4) masalah membuat peserta didik tertantang untuk mendapatkan pembelajaran di ranah pembelajaran yang baru, sehingga masalah yang digunakan dapat mengembangkan pengetahuan, sikap dan keterampilan serta kompetensi peserta didik; 5) sangat mengutamakan belajar mandiri (self directed learning); 6) memanfaatkan sumber pengetahuan yang bervariasi, tidak dari satu sumber saja. Pencarian, evaluasi serta penggunaan pengetahuan ini menjadi kunci penting; 7) pembelajaran kolaboratif, komunikatif dan kooperatif. Peserta didik bekerja dalam kelompok, berinteraksi, saling mengajarkan (peer teaching) dan melakukan presentasi; 8) menekankan pentingnya pemerolehan keterampilan meneliti, memecahkan masalah dan penguasaan pengetahuan; 9) mendorong peserta didik agar mampu berpikir 
Bioedusiana

Volume 01, nomor 01, September 2016

ISSN 2477-5193

tingkat tinggi: analisis, sintetis, fase beserta perilaku guru yang harus evaluatif; dan diakhiri dengan dilakukan dalam proses pembelevaluasi, kajian pengalaman belajar ajaran. Kelima fase tersebut dijelasdan kajian proses pembelajaran. kan pada tabel 2.3.

Pembelajaran model prob-

lem based learning terdiri dari lima

Tabel 2.3 Sintaks untuk Problem Based Learning

\begin{tabular}{|c|c|}
\hline Fase & Perilaku Guru \\
\hline $\begin{aligned} \text { Fase 1: } & \text { Memberikan orientasi } \\
& \text { tentang permasalahan- } \\
& \text { nya kepada siswa. }\end{aligned}$ & $\begin{array}{l}\text { Guru membahas tujuan pelajaran, } \\
\text { mendeskripsikan berbagai kebutuhan logistik } \\
\text { penting, dan memotivasi siswa untuk terlibat } \\
\text { dalam kegiatan mengatasi masalah. }\end{array}$ \\
\hline $\begin{aligned} \text { Fase 2: } & \text { Mengorganisasikan } \\
& \text { siswa untuk meneliti. }\end{aligned}$ & $\begin{array}{l}\text { Guru membantu siswa untuk mendefinisikan } \\
\text { dan mengorganisa-sikan tugas-tugas belajar } \\
\text { yang terkait dengan permasalahannya. }\end{array}$ \\
\hline 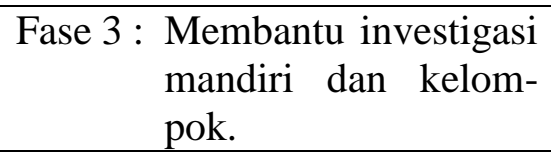 & $\begin{array}{l}\text { Guru mendorong siswa untuk mendapatkan } \\
\text { informasi yang tepat, melaksanakan } \\
\text { eksperimen, dan men-cari penjelasan dan solusi. }\end{array}$ \\
\hline $\begin{aligned} \text { Fase 4: } & \text { Mengembangkan dan } \\
& \text { mempresentasikan } \\
& \text { artefak dan exhibit. }\end{aligned}$ & $\begin{array}{l}\text { Guru membantu siswa dalam meren-canakan } \\
\text { dan menyiapkan artefak-artefak yang tepat, } \\
\text { seperti laporan, rekaman video, model-model } \\
\text { dan membantu mereka untuk menyam- } \\
\text { paikannya kepada orang lain. }\end{array}$ \\
\hline $\begin{aligned} \text { Fase 5 : } & \text { Menganalisis } \text { dan } \\
& \text { mengevalusi proses } \\
& \text { mengatasi masalah. }\end{aligned}$ & $\begin{array}{l}\text { Guru membantu siswa untuk melakukan refleksi } \\
\text { terhadap investi-gasinya dan proses-proses yang } \\
\text { mereka gunakan. }\end{array}$ \\
\hline
\end{tabular}

Sumber : Arends, Richard I (2008:57)

Model problem based menjalankan pembelajaran dengan learning memiliki banyak baik". Uden dan Beaumont keunggulan. Sebagaimana yang (Suprihatiningrum, Jamil, 2013:222) dikemukakan Amir, M Taufiq menyatakan beberapa keunggulan (2015:32) bahwa "Sesuai namanya, yang dapat diamati dari peserta didik keunggulan problem based learning yaitu: 1) mampu mengingat dengan terletak pada perancangan lebih baik informasi dan masalahnya. Masalah yang diberikan haruslah dapat merangsang dan memicu pemelajar untuk pengetahuannya; 2) mengembangkan kemampuan pemecahan masalah, berpikir kritis dan keterampilan 
Bioedusiana

Volume 01, nomor 01, September 2016 ISSN 2477-5193

komunikasi;

3) mengembangkan basis pemahaman secara integrasi; 4) menikmati belajar; 5) meningkatkan motivasi; 6) bagus dalam kerja kelompok; 7) mengembangkan belajar strategi belajar; dan 8) meningkatkan keterampilan berkomunikasi.

Norman dan Schmidt (Tan, Oon-Seng, 2003:28) mengemukakan “Ada bukti yang menunjukkan bahwa problem based learning dapat meningkatkan transfer konsep untuk masalah baru; integrasi konsep; kepentingan intrinsik dalam belajar; belajar mandiri; keterampilan belajar". Sedangkan Robert, Delisle (Tan, Oon-Seng, 2003:30) berpendapat bahwa "problem based learning bekerja dengan baik dengan semua peserta didik, membuat strategi yang ideal untuk ruang kelas yang heterogen di mana peserta didik dengan kemampuan campuran dapat menggunakan bakat mereka bersamasama untuk menciptakan solusi. Teknik ini juga membuat individu untuk orientasi interdisipliner sejak menjawab masalah yang sering memerlukan informasi dari beberapa bidang akademik".
Berdasarkan uraian di atas, maka rumusan masalah penelitian ini adalah: "Adakah pengaruh model problem based learning terhadap keterampilan berpikir kreatif peserta didik pada materi Pencemaran Lingkungan di kelas X SMA Negeri 1 Cihaurbeuti tahun ajaran 2015/2016?".

Adapun tujuan yang ingin dicapai melalui penelitian ini adalah untuk mengetahui pengaruh model problem based learning terhadap keterampilan berpikir kreatif peserta didik pada materi Pencemaran Lingkungan di kelas X SMA Negeri 1 Cihaurbeuti tahun ajaran 2015/2016.

\section{METODE PENELITIAN}

Metode penelitian yang digunakan adalah true experiment. Populasi dalam penelitian ini adalah seluruh siswa kelas X SMA Negeri 1 Cihaurbeuti tahun ajaran 2015/2016 sebanyak 4 kelas. Sampel yang digunakan dalam penelitian ini diambil dengan menggunakan teknik cluster random sampling sebanyak 2 kelas yaitu kelas X MIPA 1 sebagai kelas eksperimen dan X MIPA 2 sebagai kelas kontrol. Untuk 
Bioedusiana

Volume 01, nomor 01, September 2016

ISSN 2477-5193

mengukur keterampilan berpikir kreatif peserta didik, digunakan instrument berupa tes keterampilan berpikir kreatif berjumlah 11 butir soal yang berbentuk uraian.

Desain penenelitian yang digunakan dalam penelitian ini adalah pretest-posttest control group. Peneliti memberikan pretest terlebih dahulu kepada peserta didik sebelum dilakukan pembelajaran dan memberikan posttest setelah pembelajaran. Dengan demikian hasilnya dapat diketahui dengan akurat, karena peneliti dapat membandingkan sebelum diberikan pengajaran dan sesudah dilakukan pengajaran.

\section{HASIL PENELITIAN DAN PEMBAHASAN}

\section{Hasil Penelitian}

Tabel 1

Data Hasil Penelitian

\begin{tabular}{|l|l|l|l|}
\hline Data & Pretest & Posttest & Gain \\
\hline Kelas Eksperimen & 18,28 & 25,44 & 6,94 \\
\hline Kelas Kontrol & 15,5 & 20,5 & 5,17 \\
\hline
\end{tabular}

Tabel 2

\section{Data Hasil Uji t dependent dan t independent}

\begin{tabular}{|l|l|l|l|l|l|}
\hline \multicolumn{1}{|c|}{ Data } & $\mathbf{F}_{\text {hitung }}$ & $\mathbf{F}_{\text {tabel }}$ & Hasil Analisis & Kesimpulan & \multicolumn{1}{|c|}{ Kesimpulan Analisis } \\
\hline $\begin{array}{l}\text { Skor Pretest } \\
\text { Posttest } \\
\text { (Eksperimen) }\end{array}$ & $-13,61$ & $-2,04$ & $\mathrm{t}_{\text {hitung }}<-\mathrm{t}_{\text {tabel }}$ & Tolak Ho & $\begin{array}{l}\text { Hasil pretest tidak sama } \\
\text { dengan hasil posttest }\end{array}$ \\
\hline $\begin{array}{l}\text { Skor Pretest }- \\
\text { Posttest } \\
\text { (Kontrol) }\end{array}$ & $-12,61$ & $-2,04$ & $\mathrm{t}_{\text {hitung }}<-\mathrm{t}_{\text {tabel }}$ & Tolak Ho & $\begin{array}{l}\text { Hasil pretest tidak sama } \\
\text { dengan hasil posttest }\end{array}$ \\
\hline $\begin{array}{l}\text { Gain }{ }_{\text {eksperimen }-} \\
\text { Gain } \text { kontrol }\end{array}$ & 2,81 & 1,99 & $\mathrm{t}_{\text {hitung }}>\mathrm{t}_{\text {tabel }}$ & Tolak Ho & $\begin{array}{l}\text { Tda pengaruh model problem } \\
\text { based learning terhadap } \\
\text { keterampilan berpikir kreatif } \\
\text { peserta didik pada materi } \\
\text { Pencemaran Lingkungan di } \\
\text { kelas X SMA Negeri 1 } \\
\text { Cihaurbeuti. }\end{array}$ \\
\hline
\end{tabular}


Bioedusiana

Volume 01, nomor 01, September 2016

ISSN 2477-5193

\section{Pembahasan}

1. Proses Pembelajaraan dan Keterampilan Berpikir Kreatif Peserta Didik Kelas Eksperimen yang Menggunakan Model Problem Based Learning

Berdasarkan penelitian yang telah penulis lakukan di kelas eksperimen yang proses pembelajarannya menggunakan model problem based learning, setelah diuji dengan menggunakan uji t dependent untuk pretest dan posttest didapatkan nilai $\mathrm{t}_{\text {hitung }}=-13,61$ dan $\mathrm{t}_{\text {tabel }}=-2,04$ sehingga kesimpulan hipotesis yang didapat adalah tolak Ho, karena hasilnya $t_{\text {hitung }}<-t_{\text {tabel }}$, hal ini menunjukkan bahwa skor hasil pretest dan posttest kelas eksperimen tidak sama dan ada peningkatan. Hal ini berarti bahwa model problem based learning dapat meningkatkan keterampilan berpikir kreatif peserta didik pada materi Pencemaran Lingkungan.

Berdasarkan perolehan
skor keterampilan berpikir
kreatif dari hasil pretest dan
posttest yang masing-masing terdiri dari 11 soal uraian yang terbagai ke dalam empat aspek keterampilan berpikir kreatif yaitu 3 soal terdiri dari aspek berpikir lancar (fluency), 4 soal terdiri dari aspek berpikir luwes (flexibility), 1 soal terdiri dari aspek berpikir orisinil (originality) dan 3 soal terdiri dari aspek berpikir terperinci (elaboration). Skor maksimum yang diperoleh pada setiap soal adalah 4 dan diperoleh hasil skor yang berbeda pada setiap aspek keterampilan berpikir kreatif. Untuk lebih jelasnya skor yang diperoleh peserta didik dapat dilihat pada diagram berikut ini. 
Bioedusiana

Volume 01, nomor 01, September 2016

ISSN 2477-5193

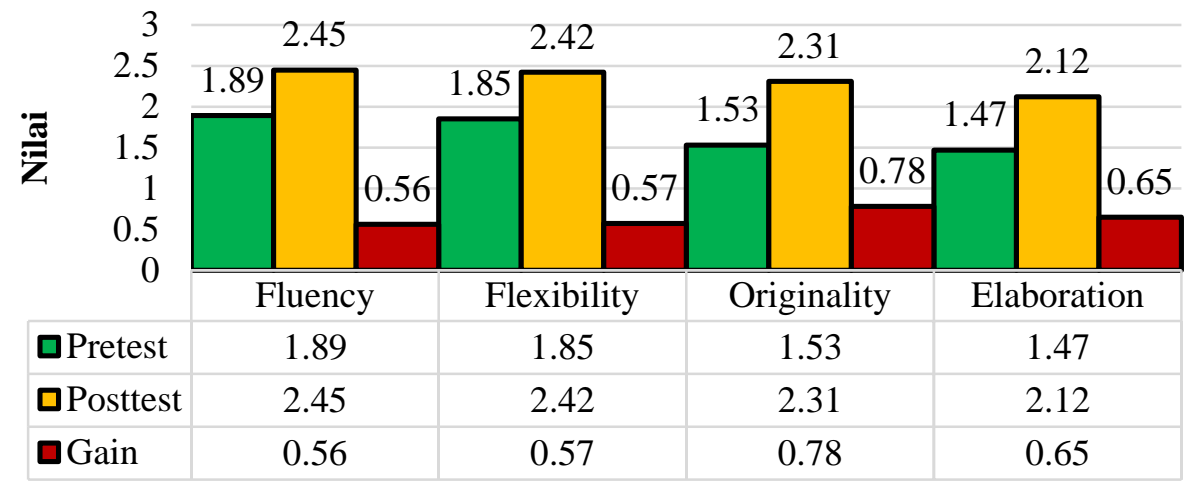

$\square$ Pretest $\square$ Posttest $\square$ Gain

Gambar 1

Diagram Rata-rata Skor Tes Keterampilan Berpikir Kreatif dalam Setiap Aspek Keterampilan Berpikir Kreatif di Kelas Eksperimen dengan Menggunakan Model Problem Based Learning

Perbedaan skor pada

setiap aspek tersebut disebab-

kan karena kriteria soal pada setiap aspek berbeda, pada soal pretest dan posttest aspek berpikir lancar (fluency) mendapatkan skor tertinggi karena soal yang dibuat berdasarkan indikator yaitu secara umum menghasilkan banyak ide dalam berbagai kategori/bidang. Hal tersebut menjadikan peserta didik mampu menghasilkan banyak gagasan dan jawaban maupun penyelesaian masalah secara relevan. Sedangkan pada aspek berpikir terperinci (elaboration) soal yang dibuat adalah memperluas suatu gagasan dan lebih memerinci terhadap suatu permasalahan yang disajikan secara lebih mendetail. Hal tersebut cukup sulit bagi peserta didik karena belum terlatih pada soal-soal uraian yang lebih terperinci.

2. Proses Pembelajaraan dan Keterampilan Berpikir Kreatif Peserta Didik Kelas Kontrol yang Menggunakan Model Discovery Learning

Berdasarkan penelitian yang telah dilakukan di kelas kontrol yang proses pembelajarannya menggunakan model discovery learning, setelah diuji dengan menggunakan uji $\mathrm{t}$ dependent untuk pretest dan posttest didapat- 
Bioedusiana

Volume 01, nomor 01, September 2016

ISSN 2477-5193

kan nilai $t_{\text {hitung }}=-12,61$ dan

$\mathrm{t}_{\text {tabel }}=-2,04$ sehingga kesim-

pulan hipotesis yang di dapat

adalah tolak Ho, karena

hasilnya $t_{\text {hitung }}<-t_{\text {tabel }}$, hal ini

menunjukkan bahwa skor

hasil pretest dan posttest kelas

kontrol tidak sama dan ada

peningkatan.

Berdasarkan perolehan skor keterampilan berpikir kreatif dari hasil pretest dan posttest yang masing-masing terdiri dari 11 soal uraian yang terbagai ke dalam empat aspek keterampilan berpikir kreatif yaitu 3 soal terdiri dari aspek berpikir lancar (fluency), 4 soal terdiri dari aspek berpikir luwes (flexibility), 1 soal terdiri dari aspek berpikir original (originality) dan 3 soal terdiri dari aspek berpikir terperinci (elaboration). Skor maksimum yang diperoleh pada setiap soal adalah 4 dan diperoleh hasil skor yang berbeda pada setiap aspek keterampilan berpikir kreatif. Untuk lebih jelasnya skor yang diperoleh peserta didik dapat dilihat pada diagram berikut ini.

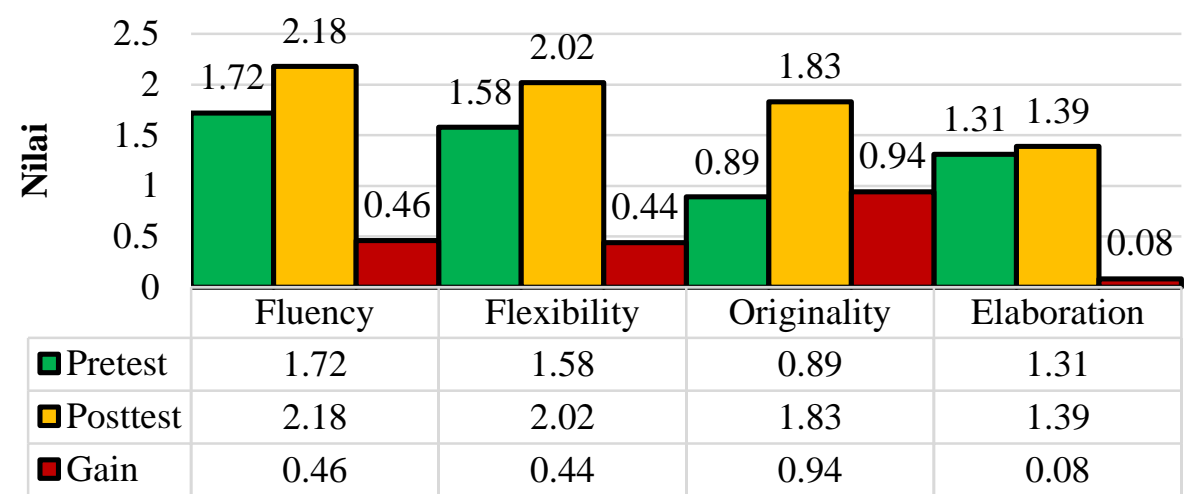

$\square$ Pretest $\square$ Posttest $\square$ Gain

Gambar 2

Diagram Rata-rata Skor Tes Keterampilan Berpikir Kreatif dalam Setiap Aspek Keterampilan Berpikir Kreatif di Kelas Kontrol dengan Menggunakan Model Discovery Learning

$\begin{array}{ccc}\text { Perbedaan skor pada } & \text { karena kriteria soal pada } \\ \text { setiap aspek disebabkan } & \text { setiap aspek berbeda, soal }\end{array}$


pretest dan posttest aspek berpikir lancar (fluency) mendapatkan skor tertinggi karena soal yang dibuat berdasarkan indikator yaitu secara umum menghasilkan banyak ide dalam berbagai kategori/bidang. Hal tersebut menjadikan peserta didik mampu menghasilkan banyak gagasan maupun penyelesaian masalah secara relevan. Sedangkan pada aspek berpikir terperinci (elaboration) soal yang dibuat adalah memperluas suatu gagasan dan lebih memerinci terhadap suatu permasalahan secara lebih mendetail. Hal tersebut cukup sulit bagi peserta didik karena belum terlatih pada soal-soal uraian yang lebih terperinci. Pada aspek berpikir orisinil (originality) juga memperoleh skor rendah karena soal yang dibuat yaitu mengharuskan peserta didik memiliki ide-ide untuk mencetuskan gagasan-gagasan yang orisinil untuk mengerjakan soal yang dapat membangun maupun mengembangkan berbagai ide maupun gagasan yang sudah ada sebelumnya.

\section{Pengaruh Model Problem} Based Learning Terhadap Keterampilan Berpikir Kreatif Peserta Didik

Berdasarkan hasil pengujian hipotesis dengan menggunakan uji $\mathrm{t}$ independent diperoleh harga $t_{\text {hitung }}=$ 2,81 sedangkan harga $t_{\text {tabel }}=$ 1,99 atau -1,99. Karena harga thitung berada di daerah penolakan Ho maka kesimpulan analisis dari penelitian ini adalah tolak Ho, artinya ada pengaruh model problem based learning terhadap keterampilan berpikir kreatif peserta didik pada materi Pencemaran Lingkungan di $\begin{array}{lllll}\text { kelas } & \mathrm{X} & \mathrm{SMA} & \text { Negeri } 1\end{array}$ Cihaurbeuti tahun ajaran 2015/2016.

Adanya pengaruh tersebut disebabkan karena model problem based learning adalah model pembelajaran dengan pendekatan pembelajaran siswa pada 
Bioedusiana

Volume 01, nomor 01, September 2016

ISSN 2477-5193

masalah autentik sehingga siswa dapat menyusun pengetahuannya sendiri, menumbuhkembangkan keterampilan yang lebih tinggi dan dapat memandirikan peserta didik serta meningkatkan kepercayaan diri sendiri. Berikut ini adalah rata-rata skor keterampilan berpikir kreatif peserta didik pada kelas eksperimen dan kelas kontrol.

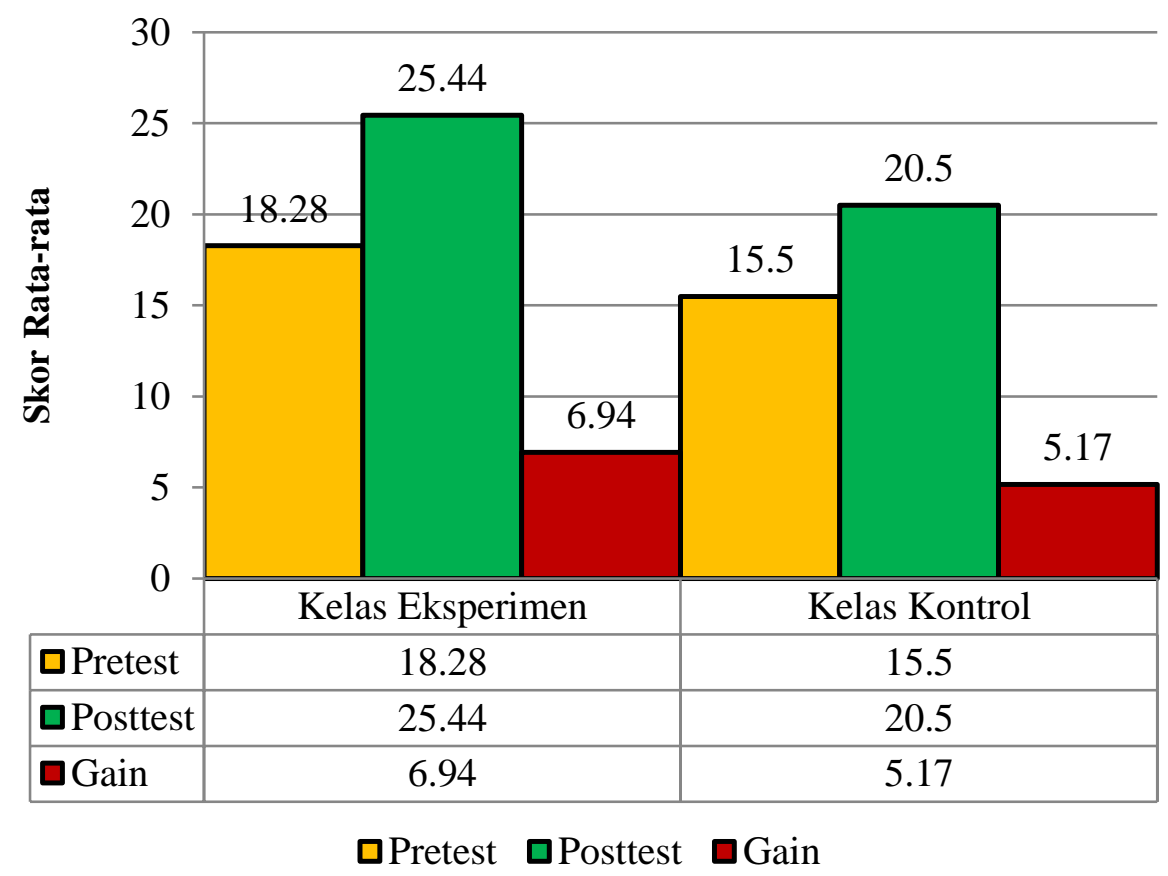

Gambar 3

Diagram Skor Rata-rata Pretest, Posttest dan Gain Keterampilan Berpikir Kreatif Peserta Didik Kelas Eksperimen dan Kelas Kontrol

Adapun Kriteria

Ketuntasan Minimal (KKM)

mata pelajaran Biologi materi

Pencemaran Lingkungan

kelas $\mathrm{X}$ di SMA Negeri 1

Cihaurbeuti hasil konversi

yaitu 23,3 . Jika di lihat dari nilai rata-rata maka proses pembelajaran yang menggu- nakan model problem based learning mencapai nilai KKM. Sedangkan proses pembelajaran yang menggunakan model discovery learning tidak mencapai nilai KKM. Hal ini membuktikan bahwa model problem based learning pada kelas 
Bioedusiana

Volume 01, nomor 01, September 2016

ISSN 2477-5193

eksperimen memiliki nilai yang lebih tinggi dibandingkan dengan peserta didik yang proses pembelajarannya menggunakan model discovery learning pada kelas kontrol.

Hal tersebut disebabkan oleh beberapa faktor, diantaranya karena model problem based learning dapat merangsang peserta didik menjadi lebih aktif dan mampu berpikir kreatif menyikapi pembelajaran serta fokus pada pemecahan masalah dan berhubung permasalahan yang diamati adalah permasalahan yang nyata sehingga menjadikan proses pembelajaran menjadi lebih bermakna bagi peserta didik. Sedangkan, peserta didik yang proses pembelajarannya menggunakan model discovery learning merupakan model berbasis penemuan yang dihadapkan pada suatu permasalahan yang sudah ditemukan sebelumnya. Permasalahan yang diberikan adalah masalah yang disajikan oleh guru, sehingga peserta didik tidak terlatih dalam penemuan ilmiah karena hanya melakukan pembuktian konsep saja.

\section{SIMPULAN DAN SARAN}

\section{Simpulan}

Berdasarkan hasil penelitian dan analisis data diperoleh simpulan Ada Pengaruh Model Problem Based Learning Terhadap Keterampilan Berpikir Kreatif Peserta Didik Pada Materi Pencemaran Lingkungan di Kelas X SMA Negeri 1 Cihaurbeuti Tahun Ajaran 2015/2016.

\section{Saran}

Berdasarkan hasil penelitian yang telah dilakukan, maka penulis menyarankan:

1. bagi guru yang akan melakukan pembelajaran dengan menggunakan model problem based learning disarankan masalah yang dikemukakan dalam pembelajaran adalah masalah nyata yang ada di sekitar sekolah maupun wilayah tempat tinggal peserta didik agar didapatkan pembelajaran bermakna yang akan membangkitkan minat serta aktivitas belajar 
Bioedusiana

Volume 01, nomor 01, September 2016

ISSN 2477-5193

peserta didik terhadap materi sehingga dapat melatih untuk dapat memecahkan masalah dengan berbagai pemikiran yang kreatif;

2. bagi peneliti selanjutnya, disarankan untuk tidak hanya menilai dari aspek kognitif meliputi data pretest dan posttest, melainkan dapat menilai dari aspek afektif dan psikomotorik; dan

3. bagi peneliti selanjutnya, dapat mencoba menggunakan model problem based learning pada materi yang berbeda dari materi yang telah peneliti gunakan.

\section{DAFTAR PUSTAKA}

Abdin, Yunus. (2014). Desain Pembelajaran dalam Konteks Kurikulum 2013. Bandung: PT Refika Aditama.

Amir, M Taufiq. (2015). Inovasi Pendidikan Melalui Problem Based Learning. Jakarta: Prenadamedia Group.

Arends, Richard I. (2008). Learning to Teach: Belajar untuk Mengajar (7th ed). Translated by Soetjipto, Helly Prajitno. Yogyakarta: Pustaka Pelajar.
Hamdayama, Jumanta. (2014). Model dan Metode Pembelajaran Kreatif dan Berkarakter. Bogor: Ghalia Indonesia.

Hosnan, M. (2014). Pendekatan Saintifik dan Kontekstual dalam Pembelajaran Abad 21. Bogor: Ghalia Indonesia.

Munandar, S.C. Utami. (2002). Kreativitas dan Keberbakatan. Jakarta: PT Gramedia Pustaka Utama.

Munandar, S.C. Utami. (2012). Kreativitas dan Keberbakatan. Jakarta: PT Rineka Cipta.

Rachman, Niken Noviasti. (2013). "Pengaruh Model Pembelajaran Berbasis Proyek Terhadap Keterampilan Berpikir Kritis dan Kreatif Siswa Kelas VIII pada Materi Pertumbuhan dan Perkembangan Tumbuhan". Tesis. Program Studi Pendidikan IPA Konsentrasi Biologi Sekolah Pascasarjana. Universitas Pendidikan Indonesia. Bandung: tidak diterbitkan.

Saefudin, Abdul Aziz. (2012). "Pengembangan Kemampuan Berpikir Kreatif dalam Pembelajaran Matematika dengan Pendekatan Pendidikan Matematika Realistik Indonesia (PMRI)". AlBidayah. 4(1). Universitas PGRI Yogyakarta. 
Bioedusiana

Volume 01, nomor 01, September 2016

ISSN 2477-5193

Sanjaya, Wina. (2011). Strategi Pembelajaran Berorientasi Standar Proses Pendidikan. Jakarta: Kencana Prenada Media.

Suprihatiningrum, Jamil. (2013). Strategi Pembelajaran. Jogjakarta: Ar-Ruzz Media.
Tan, Oon-Seng. (2003). Problem Based Learning Innovation: Using Problems to Power Learning in the 21st Century. Singapore: Cengage Learning.

Tawil, Muh dan Liliasari. (2013). Berpikir Kompleks. Makassar: Badan Penerbit UNM. 